\title{
Extracellular superoxide dismutase is a thyroid differentiation marker down-regulated in cancer
}

\section{Lilja E Laatikainen ${ }^{1}$, Maria D Castellone ${ }^{2}$, Aline Hebrant ${ }^{3}$, Candice Hoste ${ }^{3}$, Maria C Cantisani ${ }^{2}$, Juha $P$ Laurila ${ }^{1}$, Giuliana Salvatore ${ }^{4}$, Paolo Salerno ${ }^{2}$, Fulvio Basolo ${ }^{5}$, Johnny Näsman ${ }^{6}$, Jacques E Dumont ${ }^{3}$, Massimo Santoro ${ }^{2}$ and Mikko O Laukkanen ${ }^{1,7}$}

\footnotetext{
${ }^{1}$ Cellular Therapy Group, Medicity Research Laboratory, University of Turku, Tykistökatu 6A, FIN-20520 Turku, Finland

${ }^{2}$ Institute of Experimental Endocrinology and Oncology (CNR), C/o Department of Biology and Cellular and Molecular Pathology, University of Naples Federico II, Via Pansini, 80014 Naples, Italy

${ }^{3}$ Institut de Recherche Interdisciplinaire en Biologie Humaine et Moléculaire, Université Libre de Bruxelles, Campus Erasme, Bruxelles B-1083, Belgium

${ }^{4}$ Dipartimento di Studi delle Istituzioni e dei Sistemi Territoriali, Universita' 'Parthenope', 80133 Naples, Italy

${ }^{5}$ Dipartimento di Chirurgia, Università di Pisa, 56126 Pisa, Italy

${ }^{6}$ Åbo Akademi University, Tykistökatu, 20520 Turku, Finland

${ }^{7}$ Fondazione IRCCS SDN, Via Gianturco, 80143 Naples, Italy
}

(Correspondence should be addressed to M O Laukkanen at Cellular Therapy Group, Medicity Research Laboratory, University of Turku; Email: mikko.laukkanen@utu.fi)

\begin{abstract}
Reactive oxygen species, specifically hydrogen peroxide $\left(\mathrm{H}_{2} \mathrm{O}_{2}\right)$, have a significant role in hormone production in thyroid tissue. Although recent studies have demonstrated that dual oxidases are responsible for the $\mathrm{H}_{2} \mathrm{O}_{2}$ synthesis needed in thyroid hormone production, our data suggest a pivotal role for superoxide dismutase 3 (SOD3) as a major $\mathrm{H}_{2} \mathrm{O}_{2}$-producing enzyme. According to our results, Sod3 is highly expressed in normal thyroid, and becomes even more abundant in rat goiter models. We showed TSH-stimulated expression of Sod3 via phospholipase $\mathrm{C}-\mathrm{Ca}^{2+}$ and cAMP-protein kinase $\mathrm{A}$, a pathway that might be disrupted in thyroid cancer. In line with this finding, we demonstrated an oncogene-dependent decrease in Sod3 mRNA expression synthesis in thyroid cancer cell models that corresponded to a similar decrease in clinical patient samples, suggesting that SOD3 could be used as a differentiation marker in thyroid cancer. Finally, the functional analysis in thyroid models indicated a moderate role for SOD3 in regulating normal thyroid cell proliferation being in line with our previous observations.
\end{abstract}

Endocrine-Related Cancer (2010) 17 785-796

\section{Introduction}

The $\mathrm{G}$ protein-coupled receptor (GPCR) activating $\mathrm{G} \alpha_{\mathrm{s}}$ and $\mathrm{G} \alpha_{\mathrm{q}}$ proteins, such as TSH receptor (TSH-R), mediate the cellular responses to various extracellular stimuli via two main signal transduction pathways: the cAMP pathway and the phosphatidylinositol pathway that is involved in calcium signaling (Pierce et al. 2002). In thyroid, the TSH-R cAMP pathway is responsible for the thyroid cell proliferation, differentiation, and secretion, whereas the TSH-R phosphatidylinositol cascade controls thyroid hormone tri-iodothyronine $\left(\mathrm{T}_{3}\right)$ and thyroxine $\left(\mathrm{T}_{4}\right)$ synthesis. The TSH is crucially important for normal thyroid function, and therefore, deregulation caused by, e.g. TSH-R mutations or external factors, affecting TSH signaling interferes with the cellular homeostasis in thyroid (Ludgate \& Vassart 1995). A low iodide uptake leads to reduced thyroid hormone $\mathrm{T}_{3}$ and $\mathrm{T}_{4}$ production (hypothyroidism), which is compensated by increased TSH synthesis and subsequent activation of downstream signaling leading to cell proliferation and benign thyroid enlargement known as goiter (Dumont et al. 1989). Similarly, activating mutations of the TSH-R cause autonomous hyperfunctioning thyroid adenomas 
and nonautoimmune toxic thyroid hyperplasia (Duprez et al. 1994).

TSH signaling has been shown to increase the synthesis of hydrogen peroxide $\left(\mathrm{H}_{2} \mathrm{O}_{2}\right)$, which is used as an extracellular substrate by thyroperoxidase in thyroglobulin iodination and thyroid hormone synthesis (Corvilain et al. 1991). On the other hand, intracellular $\mathrm{H}_{2} \mathrm{O}_{2}$ contributes to mitogen signaling and consequent cellular proliferation in in vitro and in vivo models (Rao \& Berk 1992, Guyton et al. 1996, Kuroki et al. 1996) by regulating the activation of protein tyrosine phosphatases and tyrosine kinase receptors (Rao 1997, Wang et al. 2000, Saito et al. 2002, Aslan \& Ozben 2003, Konishi et al. 2004, Mehdi et al. 2005). We have previously demonstrated the ability of extracellular superoxide dismutase (SOD3), which is one of the main $\mathrm{H}_{2} \mathrm{O}_{2}$-producing enzymes (Marklund 1984, Karlsson \& Marklund 1987), to promote cell proliferation in vivo by activating Ras-Erk mitogen signaling, transcription factor upregulation and growth factor expression suggesting growth stimulatory role in tissues (Laurila et al. 2009).

In the current study, we investigated the signal transduction pathways and synthesis of Sod3 in different experimental models to determine the function of SOD3-derived $\mathrm{H}_{2} \mathrm{O}_{2}$ in thyroid. We identified a novel TSH-R-mediated signaling pathway activating Sod3 synthesis and decreased SOD3 expression in thyroid malignancies.

\section{Materials and methods}

\section{Animals}

Male 4-5 weeks old Sprague-Dawley rats (University of Turku, Turku, Finland) were given $0.25 \%$ propylthiouracil (PTU; Sigma) ad libitum in drinking water for 2 weeks, killed, and tissues were collected for expression analysis. As controls for histological staining, we used nontreated rat thyroids, and for quantitative reverse transcription (qRT)-PCR analysis, a thyroid total RNA pool from four animals. Experimental procedures were done according to the European Union and the University of Turku guidelines (permission 2009/2502).

\section{Histological analysis}

Thyroid tissues were embedded in optimal cutting temperature compound, OCT (Tissue-Tek, Torrance, CA, USA). Ten-micrometer sections were stained with hematoxylin/eosin (Sigma) according to the standard protocols.

\section{Cell lines and reagents}

Rat PC Cl3 cells were grown in Ham's F-12 medium, Coon's modified (Sigma) supplemented with 5\% calf serum (Life Technologies, Inc.) and $10 \mathrm{nM} \mathrm{TSH}$, $10 \mathrm{nM}$ hydrocortisone, $100 \mathrm{nM}$ insulin, $5 \mu \mathrm{g} / \mathrm{ml}$ transferrin, $5 \mathrm{nM}$ somatostatin, and $20 \mu \mathrm{g} / \mathrm{ml}$ glycylhistidyl-lysine. PC RET/PTC1 and PC E1A stable cell lines, kindly provided by Prof. Alfredo Fusco, were grown in F-12 medium supplemented with 5\% calf serum without hormones (Fusco et al. 1987, Santoro et al. 1993). PC-inducible RET/PTC1 cells were grown in the same medium as PC Cl3 cell administered with $1 \mu \mathrm{g} / \mathrm{ml}$ doxycyclin (Sigma). COS-7 cells were grown in DMEM (Sigma) supplemented with $10 \%$ fetal bovine serum (Life Technologies, Inc). Transfections ( $1 \mu \mathrm{g}$ of plasmid) were done with Fugene6 (Roche Applied Science) for $\mathrm{PC} \mathrm{Cl} 3$ cells, and with Polyfect (Sigma) for COS-7 cells. Human SOD3 cDNA, kindly provided by Prof. Stefan L Marklund from the University of Umeå, Sweden, was cloned to pcDNA3 vector (Life Technologies). The plasmids pCEF- $G \alpha_{\mathrm{s}}$ and pCEF- $G \alpha_{\mathrm{q}}$, encoding constitutive active form (QL) of $G \alpha_{\mathrm{s}}$ and $G \alpha_{\mathrm{q}}$ and pCEF-protein kinase A ( $P K A)$, encoding the active catalytic subunit of PKA, were kindly provided by Dr Silvio Gutkind from NIH, MD, USA. PC Cl3 cells were incubated with $10 \mathrm{nM}$ TSH (Sigma), $40 \mu \mathrm{M}$ forskolin (Sigma), $1 \mu \mathrm{M} N(2-((\rho$-bromocinnamyl)amino)ethyl)-5isoquinolinesulfonamide (H89; Calbiochem, San Diego, CA, USA), or $100 \mathrm{nM}$ thapsigargin (Research Biochemicals International, Natick, MA, USA). SOD1 protein was purchased from Sigma.

\section{PCRs}

Total RNA was isolated from tissues pooled from four animals or cells using Tri-reagent (Sigma). The firststrand synthesis was done with QuantiTect RT (Qiagen) and qPCR with SYBR Green PCR master mix (Applied Biosystems, Foster City, CA, USA). Primers were rat Sodl-for GTC GTC TCC TTG CTT TTT GC and rat Sodl-rev TGC TCG CCT TCA GTT AAT CC; rat $S o d 2$-for AAG GAG CAA GGT CGC TTA CA and rat $S o d 2$-rev TGG CTA ACA TTC TCC CAG TTG; rat Sod3-for GAC CTG GAG ATC TGG ATG GA and rat $S o d 3$-rev GTG GTT GGA GGT GTT CTG CT; human SOD3-for CTT CGC CTC TGC TGA AGT CT and human SOD3-rev GGG TGT TTC GGT ACA AAT GG; human $\beta A C T I N$-for TGC GTG ACA TTA AGG AGA AG and human $\beta A C T I N$-rev GCT CGT AGC TCT TCT CCA; rat $\beta$ Actin-for TCG TGC GTG ACT TAA GGA G and rat $\beta$ Actin-rev GTC AGG CAG CTC GTA GCT CT. Reactions were done in $60{ }^{\circ} \mathrm{C}$ annealing temperature. 


\section{Real-time PCR tissue samples}

The qRT-PCR expression analyses from human tissues were done to normal thyroid $(n=7)$, papilloma thyroid cancer (PTC, $n=9$ ), and anaplastic thyroid cancer (ATC, $n=6$ ) patient samples. The PTC patient samples had 30\% genetic variation (six wild-type Braf, one Braf V600E, and two RET/PTC1 rearrangements). Five ATC patient samples had Braf V600E mutation and one had wild-type Braf. The analysis of mRNA expression was done from pooled samples.

\section{DNA array tissue samples}

The diagnoses of the hyperthyroidic patients were based on the long-standing hyperthyroidism, absence of thyroid-stimulating antibodies in the serum and in some cases, family history and confirmed by DNA sequencing of the TSH-R. The details of the patient material were described earlier (Hebrant et al. 2009). Shortly, thyroid samples were obtained from five familial nonautoimmune hyperthyroidism (FNAH) French patients (from Nancy (FNAH1 and FNAH4), Reims (FNAH2), Lyon (FNAH3), and Angers (FNAH5)), autonomous adenoma (AA) samples were obtained and pooled from four different patients as published previously (Hebrant et al. 2009).

In order to compare FNAH and AA, we used the reference pool of 23 normal thyroid tissues adjacent to different pathologies. The human HEEBO (human exonic evidence-based oligonucleotide) 70-mer oligonucleotide microarrays, containing $\sim 48500$ probes (representing exonic sequences, alternatively spliced exons, expressed sequence tags (ESTs), and controls) were used for the array analysis. All hybridizations were performed in duplicates with dye swap. For the PTC and ATC microarray, 20 PTCs and 9 ATCs were hybridized on Affymetrix slides (HGU133 plus 2.0), according to Affymetrix protocol. The ethics committees of the institutions have approved protocols according to Declaration of Helsinki.

\section{Calcium uptake assay}

Intracellular $\mathrm{Ca}^{2+}$ concentrations were measured in $\mathrm{PC} \mathrm{Cl} 3$ cells. Briefly, cells were detached from tissue culture plates with PBS containing $0.5 \mathrm{mmol} / \mathrm{l}$ EDTA, washed once with HEPES-buffered medium (HBM; $137 \mathrm{mmol} / \mathrm{l} \mathrm{NaCl}, 5 \mathrm{mmol} / \mathrm{l} \mathrm{KCl}, 1 \mathrm{mmol} / 1 \mathrm{CaCl}_{2}$, $0.44 \mathrm{mmol} / 1 \mathrm{KH}_{2} \mathrm{PO}_{4}, 4.2 \mathrm{mmol} / 1 \mathrm{NaHCO}_{3}, 10 \mathrm{mmol} / \mathrm{l}$ glucose, $20 \mathrm{mmol} / \mathrm{l} \mathrm{HEPES}$, and $1.2 \mathrm{mmol} / 1 \mathrm{MgCl}_{2}$, $\mathrm{pH}$ 7.4), and then loaded with $2 \mu \mathrm{mol} / \mathrm{l}$ fura-2 acetoxymethyl ester for $20 \mathrm{~min}$ at $37^{\circ} \mathrm{C}$. After loading, the cells were diluted with $\mathrm{HBM}$ without $\mathrm{CaCl}_{2}$ to a final concentration of $0.3 \mathrm{mmol} / \mathrm{l} \mathrm{CaCl}_{2}$ and stored at room temperature until use. For fluorescence recordings, an appropriate volume of the cell suspension was spun down, washed once in HBM, resuspended in $\mathrm{HBM}$, and placed in a thermostated $\left(37^{\circ} \mathrm{C}\right)$ cuvette with magnetic stirring in a Hitachi F-2000 fluorescence spectrophotometer. The fluorescence was monitored at $340 \mathrm{~nm}$ (excitation) and $505 \mathrm{~nm}$ (emission). Experiments were calibrated with $60 \mu \mathrm{g}$ digitonin $/ \mathrm{ml}\left(F_{\max }\right)$ and $10 \mathrm{mmol} / \mathrm{l}$ EGTA $\left(F_{\min }\right)$. The intracellular $\left[\mathrm{Ca}^{2+}\right]$ was calculated from the fluorescence $(F)$ using the equation $\left[\mathrm{Ca}^{2+}\right]=\left(F-F_{\min }\right) /\left(F_{\max }-F\right) \times 224 \mathrm{nmol} / \mathrm{l}$ $\left(K_{\mathrm{d}}\right.$ for fura-2), in which the extracellular fura-2 fluorescence was subtracted from $F$ values.

\section{RNA interference}

Short interfering Sod3 or Gapdh OnTargetplus SMART pool oligos (Dharmacon, Lafayette, CO, USA) were transfected into $\mathrm{PC} \mathrm{Cl} 3$ cells according to the manufacturer's protocol. Shortly, $20 \mu \mathrm{mol} / \mathrm{l}$ of siSOD3 or siGAPDH control oligo were resuspended to total volume $100 \mu \mathrm{l}$ transfection buffer, mixed with equal volume of Optimem (Life Technologies), and incubated $5 \mathrm{~min}$ at room temperature. The optimation of small interference RNA (siRNA) quantity used in the study was based on the siGAPDH silencing effect using KDalert GAPDH assay kit (Ambion, Austin, TX, USA). To prepare the transfection solution, $5 \mu \mathrm{l}$ Dharmafect 4 reagent was added to $190 \mu \mathrm{l}$ of Optimem and incubated $5 \mathrm{~min}$ at room temperature. Oligo suspension and transfection reagent were combined, incubated $20 \mathrm{~min}$ at room temperature, and added to the cells for $48 \mathrm{~h}$.

\section{Bromodeoxyuridine analysis}

Cells were serum starved for $16 \mathrm{~h}$ and TSH stimulated for $6 \mathrm{~h}$ before the addition of $10 \mathrm{mM}$ bromodeoxyuridine (BrdU; Roche) for $2 \mathrm{~h}$. Subsequently, cells were fixed in 3\% paraformaldehyde (Sigma) and permeabilized with $0.2 \%$ Triton X-100 (Sigma). BrdU-positive cells were revealed with FITC-conjugated secondary antibodies (Jackson ImmunoResearch Laboratories, Inc., West Grove, PA, USA). Cell nuclei were identified by Hoechst (Sigma) staining.

\section{Chemiluminescence assay for $\mathrm{O}_{2}^{--}$detection}

Extracellular $\mathrm{O}_{2}^{--}$release was detected by chemiluminescence using the SOD-inhibitable Diogenes reagent (National Diagnostics, Atlanta, GA, USA) on cells resuspended in Hanks' Balanced Salt Solution (HBSS) $/ 10 \mathrm{mmol} / \mathrm{l}$ glucose. One $\mu \mathrm{mol} / \mathrm{l}$ ionomycin was added to the cells to stimulate the dual oxidase (DUOX) 
activity. Measurements were taken with $22 \mathrm{~s}$ intervals for $10 \mathrm{~min}$ in 96 -well white plates $\left(1.5 \times 10^{5}\right.$ cells $/ 250-\mu 1$ well) at $37^{\circ} \mathrm{C}$ using a Microplate Luminometer. Chemiluminescence curves were analyzed, and peak values of the curves were presented in Relative Light Units/s.

\section{Fluorimetric assay for $\mathrm{H}_{2} \mathrm{O}_{2}$ detection}

The $\mathrm{H}_{2} \mathrm{O}_{2}$ release was quantified $48 \mathrm{~h}$ after cell transfection by the homovanillic acid-based fluorimetric assay (Benard \& Brault 1971) and by 5-(and-6)-chloromethyl-2', $7^{\prime}$-dichlorodihydrofluorescein diacetate $\left(\mathrm{H}_{2} \mathrm{DCFDA}\right.$; Invitrogen). For homovanillic assay, the cells were incubated in Krebs-Ringer-HEPES medium $\mathrm{pH} 7.4$ containing $0.1 \mu \mathrm{g} / \mathrm{ml}$ HRP type II, $440 \mu \mathrm{mol} / \mathrm{l}$ homovanillic acid, and $1 \mu \mathrm{mol} / \mathrm{l}$ ionomycin during $2 \mathrm{~h} 30 \mathrm{~min}$ at $37^{\circ} \mathrm{C}$. Fluorescence intensity of oxidized homovanillic acid was measured at $425 \mathrm{~nm}$ after excitation at $315 \mathrm{~nm}$. Results are reported as $\mathrm{ng}$ of $\mathrm{H}_{2} \mathrm{O}_{2}$ /well representing the quantity of $\mathrm{H}_{2} \mathrm{O}_{2}$ accumulated during $2 \mathrm{~h} 30 \mathrm{~min}$ in each well (six-well plates). For the $\mathrm{H}_{2} \mathrm{DCFDA}$ assay, the cells were grown in 96-well dishes, the reagent $(1 \mathrm{mg} / \mathrm{ml})$ was added to the cells for $15 \mathrm{~min}$, and the fluorescence was measured with $\mathrm{A}_{380} / \mathrm{A}_{435}$.

\section{Statistical analysis}

Statistical analysis was done using $t$-test for means \pm S.D.

\section{Results}

\section{SOD3 is abundantly expressed in rat thyroid tissue and stimulated by TSH}

SOD3 is an extracellular $\mathrm{H}_{2} \mathrm{O}_{2}$-producing enzyme expressed in various tissues (Marklund 1984, Laukkanen et al. 2000) protecting cell surface structures against deleterious effects of superoxide. The local administration of Sod3, causing twofold increased total SOD activity in tissues, or i.v. infusion of the native $\mathrm{C}$-form of the isolated recombinant enzyme with affinity to cell surface structures results in significant attenuation of tissue damages and markedly increased tissue recovery (Hatori et al. 1992, Sjoquist \& Marklund 1992, Laukkanen et al. 2002), suggesting that even minor changes in tissue SOD3 concentration have a significant impact on the redox balance.

Comparison of SOD isoenzyme mRNA expressions from normal rat tissues (Fig. 1A) demonstrated thyroid as one of the major expression sites for Sod3. Accordingly, mRNA extraction from normal rat tissues showed 2.5-fold higher expression levels in thyroid as compared with heart, corresponding to a previously reported threefold and fivefold differences in thyroid versus heart protein level in rabbit and human respectively (Marklund 1984). The expression in the rat thyroid approached the levels detected in the aorta, which is one of the main expression sites for SOD3 (Laukkanen et al. 2002), indicating participation to ROS balance and signal transduction in thyroid tissue. The expression of Sod1 and Sod2 was in line with previously reported enzyme activities in the rat tissues (Marklund 1984).

Because SOD3 activation increases $\mathrm{H}_{2} \mathrm{O}_{2}$ synthesis that has been shown to be up-regulated in response to $\mathrm{TSH}$, we used a rat in vivo model to investigate the expression status of SOD3 in benign thyroid enlargement caused by increased TSH secretion and to compare the animal data to human clinical samples. PTU treatment is known to cause decreased $T_{3}$ production with subsequent increase in $\mathrm{TSH}$, thyroid enlargement, and activated thyroid function (Levey 1963, al-Alawi et al. 1995, Laezza et al. 2006); we therefore treated four rats with PTU ad libitum and killed the animals after 2 weeks to isolate the thyroids. As shown in Fig. 1, PTU-treated thyroids had on average fourfold increase in wet-weight (animals 4-7) as compared with normal untreated animals (rat 1-3; Fig. 1B), suggesting a typical goiter formation, which was further supported by hematoxylin-eosin staining demonstrating increased cellular division and loss of follicular lumen (Fig. 1C and D). The variation seen in thyroid growth is in line with previous reports (Levey 1963) due to ad libitum administration of PTU. To study the expression of Sod3 mRNA, we pooled in two separate groups the normal and the treated rats, and showed tenfold increased $(P<0.01)$ mRNA synthesis in PTU-treated animals (Fig. 1E), thereby suggesting that the enzyme production is activated by TSH signaling. However, the DNA array analysis of human AA and FNAH samples failed to demonstrate significant differences between patient groups (Fig. 1F), suggesting that the human phenotype is milder than the phenotype of PTU-treated rats.

We then extended our analysis to clinical thyroid patient samples by comparing the SOD isoenzyme expression in normal human thyroid (Fig. 1G) and found that in humans, SOD1 showed highest degree of expression differently from the rat thyroid samples (Fig. 1A). Finally, in order to confirm the significance of SOD3 in thyroid cell physiology, we compared the expression of $\operatorname{Sod} 1, \operatorname{Sod} 2$, and $\operatorname{Sod} 3$ in a normal thyroid rat cell line ( $\mathrm{PCCl} 3)$. According to qRT-PCR data, Sod3 expression was significantly higher as compared with Sodl $(P<0.01)$ and $\operatorname{Sod} 2(P<0.01$; Fig. $1 \mathrm{H})$ validating the in vivo observations in the rat model (Fig. 1A). 
A

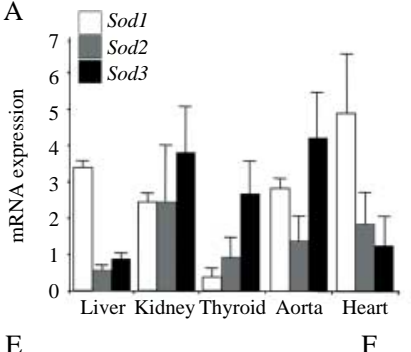

E

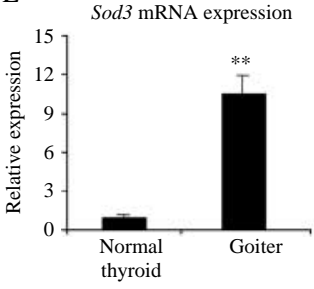

B

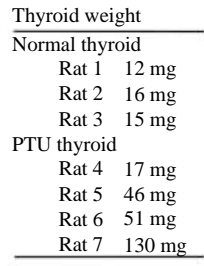

F

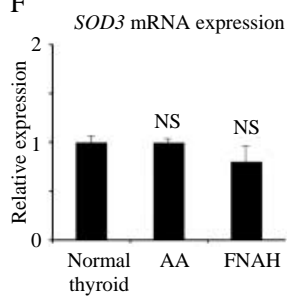

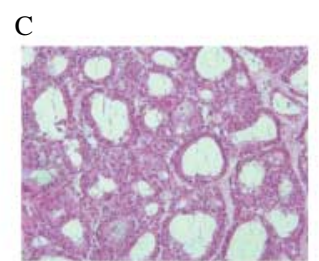

G

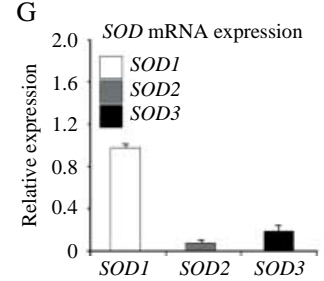

D

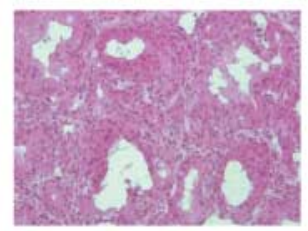

$\mathrm{H}$

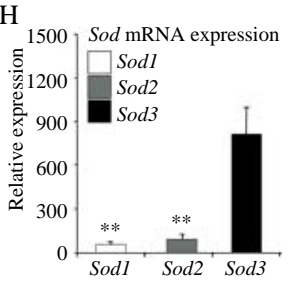

Figure 1 Superoxide dismutase expression in rat and human tissues. (A) Quantitative RT-PCR analysis for Sod1, Sod2, and Sod3 mRNA expression from normal untreated rat tissues. The analysis suggested high expression level for Sod1 in liver, kidney, aorta, and in heart; for Sod2 in kidney; and for Sod3 in kidney, thyroid, and aorta. (B) Thyroid weight measurement from three normal and four PTU-treated rats. Rats 1-3: normal controls, rats 4-7: PTU-treated animals. The analysis showed approximately fourfold increase in wet weight of the PTU-treated tissues indicating goitrogenous development. The use of PTU ad libitum for 14 days in drinking water caused variation seen in thyroid weight development. (C and D) Hematoxylin-eosin staining for control rats (C) and for PTU-treated rats (D) showed hyperplasia and altered thyroid structure caused by the treatment. (E) Sod3 mRNA expression upon PTU treatment. The Sod3 levels in rat thyroid were significantly $(P<0.01)$ increased by PTU treatment. (F) Human DNA array analysis from normal thyroid, autonomous adenoma (AA), and from familial nonautoimmune hyperthyroidism (FNAH) showed insignificant differences for SOD3 mRNA expression. (G) Real-time RT-PCR analysis for SOD mRNA expression from normal human thyroid samples. In human thyroid tissue, SOD1 represents the major isoenzyme differently from rat thyroid tissue shown in panel 1A. (H) Comparison of Sod1, Sod2, and Sod3 expression in rat thyroid PC Cl3 cells by real-time RT-PCR analysis suggested Sod3 as a major isoenzyme in the cell line being in line with normal rat thyroid expression analysis shown in panel $1 \mathrm{~A}$. Sod3 synthesis was significantly $(P<0.01)$ higher than Sod1 and Sod2 mRNA production.

\section{TSH signal transduction increases Sod3 mRNA expression}

The upregulation of SOD3 in rat hyperfunctioning thyroids suggests that SOD3 could be under the control of TSH, and therefore, we investigated the effect of the different mediators of TSH signaling on regulating Sod3 production in rat $\mathrm{PC} \mathrm{Cl} 3$ cell line. As shown in Fig. 2A, the SOD3 mRNA synthesis was significantly induced by TSH stimulation (threefold increase, $P<0.01)$. Because TSH-R is coupled to both $\mathrm{G}$ proteins: to $G \alpha_{\mathrm{s}}$, which causes accumulation of cAMP and activates PKA, and to $G \alpha_{\mathrm{q}}$, which increases the intracellular $\mathrm{Ca}^{2+}$ level and activates protein kinase $\mathrm{C}$ (PKC), we studied the contribution of $G \alpha_{\mathrm{s}}$-mediated pathway on Sod3 mRNA production by transiently transfecting constitutively active $G \alpha_{\mathrm{s}}\left(\mathrm{pCEF}-G \alpha_{\mathrm{s}}\right)$ and PKA (pCEF- $P K A$ ) into $\mathrm{PC} \mathrm{Cl} 3$ cells that resulted in 5.5 -fold $(P<0.01)$ and sixfold increase $(P<0.001)$ in SOD3 mRNA synthesis respectively. Similarly, accumulation of cAMP after the activation of adenylyl cyclase with forskolin promoted Sod3 mRNA transcription of sixfold $(P<0.05)$, supporting the involvement of TSH-cAMP pathway in the production of
SOD3. To further demonstrate the specificity of Sod3 activation, we inhibited the PKA function in TSHstimulated $\mathrm{PC} \mathrm{Cl} 3$ cells by using a selective PKA inhibitor, H89. Interestingly, even though TSH-H89 incubation significantly decreased $(P<0.05)$ Sod3 production, it was not able to completely abolish the mRNA induction, suggesting the contribution of other signaling routes in SOD3 regulation (Fig. 2A). Because in thyroid cells TSH-derived signaling is also mediated via $\mathrm{G} \alpha_{\mathrm{q}}-\mathrm{PLC}-\mathrm{Ca}^{2+}$ signal transduction pathway (Song et al. 2007), we transfected $\mathrm{PC} \mathrm{Cl} 3$ cells with an active form of $G \alpha_{\mathrm{q}}\left(\mathrm{pCEF}-G \alpha_{\mathrm{q}}\right)$ or incubated the cells with thapsigargin, which increases calcium influx. Transfection of pCEF- $G \alpha_{\mathrm{q}}$ as well as treatment with thapsigargin increased relative mRNA production by threefold $(P<0.01$ and $P<0.05$ respectively; Fig. 2B and $\mathrm{C}$ ), suggesting that both $\mathrm{G} \alpha_{\mathrm{s}} / \mathrm{cAMP} / \mathrm{PKA}$ and $\mathrm{G} \alpha_{\mathrm{q}} / \mathrm{PKC} \gamma / \mathrm{Ca}^{2+}$ signal transduction pathways are involved in SOD3 regulation in $\mathrm{PC} \mathrm{Cl} 3$ cells. The effect of thapsigargin on promoting the $\mathrm{Ca}^{2+}$ levels in $\mathrm{PC} \mathrm{Cl} 3$ cells was determined by measuring the intracellular $\mathrm{Ca}^{2+}$ concentrations at different time points, upon treatment with the compound (Fig. 2C). 

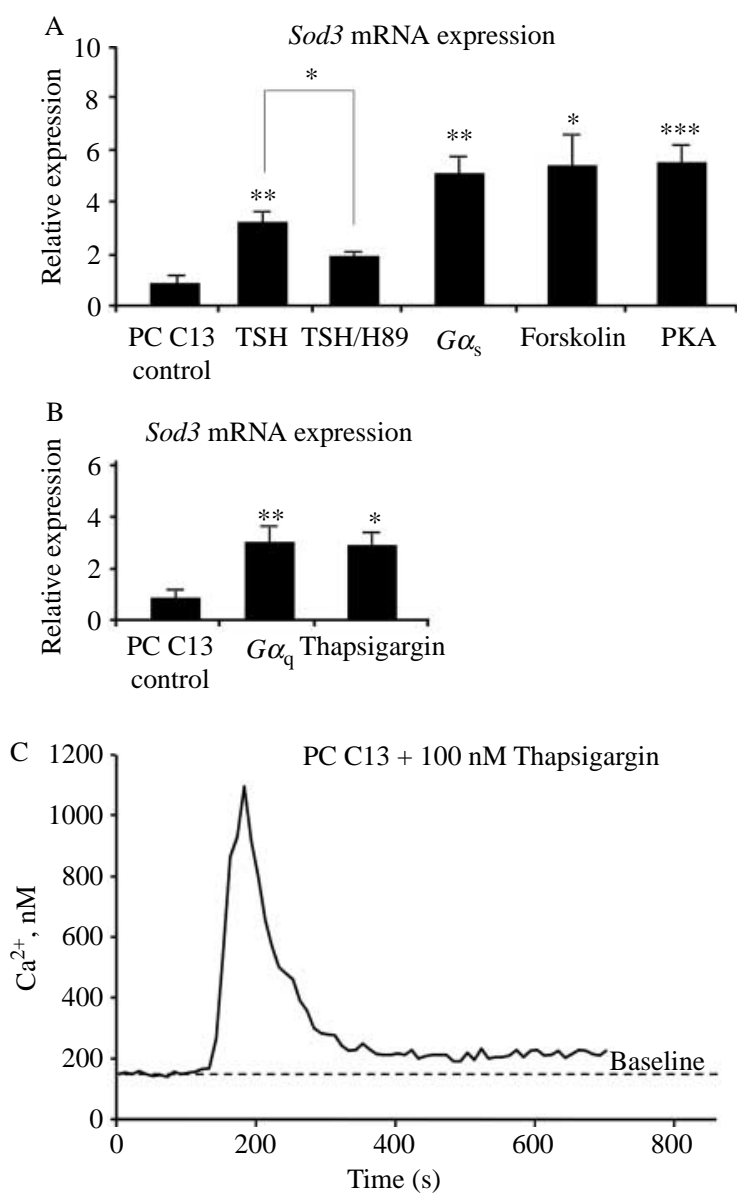

Figure 2 TSH activation increased Sod3 mRNA production in PC Cl3 cells. (A) TSH-R cAMP pathway increased Sod3 production. The expression was analyzed by qRT-PCR in cells treated with TSH and forskolin or transfected with PKA or $G \alpha_{s}$, which all induced the mRNA synthesis significantly $(P<0.01$, $P<0.05, P<0.001$, and $P<0.01$ respectively). Treatment with PKA inhibitor $\mathrm{H} 89$ reduced significantly $(P<0.05)$ the effect of TSH but was not able to completely inhibit the expression. (B) The effect of TSH-R phophatidylinositol cascade on Sod3 synthesis was studied by $G \alpha_{\mathrm{q}}$ subunit transient transfection and by calcium uptake analysis using thapsigargin that blocks the calcium pumps in endoplasmic reticulum increasing the cytosolic calcium concentration. Both treatments, transfection and thapsigargin administration, increased the mRNA synthesis significantly $(P<0.01$ and $P<0.05$ respectively). (C) The intracellular calcium levels upon thapsigargin treatment were measured by fluorescent calcium uptake assay. The levels went promptly up after $100 \mathrm{nmol} / \mathrm{l}$ thapsigargin administration and stayed above the baseline values over the follow-up period.

\section{SOD3 has a mitogenic effect in thyroid cells}

We then aimed to investigate the physiological consequences of TSH-stimulated Sod3 production in thyroid cells. In addition to antioxidative characteristics, we have recently shown that exogenously administered Sod3 is able to stimulate Ras GTP loading in vitro and in vivo leading to the activation of mitogen signaling pathway and consequent growth factor expression and cell proliferation (Laurila et al. 2009). This is further supported by numerous reports showing that physiological concentrations of $\mathrm{H}_{2} \mathrm{O}_{2}$ can activate cell membrane receptors and downstream signaling leading to cell proliferation in vitro and in vivo (Rao 1997, Wang et al. 2000, Saito et al. 2002, Aslan \& Ozben 2003, Konishi et al. 2004, Mehdi et al. 2005).

Since $\mathrm{Sod} 3$ is highly expressed in $\mathrm{PC} \mathrm{Cl} 3$ cells (Fig. 1H), the overexpression of SOD3 did not have any detectable effect on cell proliferation (data not shown). We therefore investigated the effect of RNAi on normal rat thyroid cell proliferation. The efficiency of Sod 3 siRNA transfection was checked by qRT-PCR analysis, showing 95\% interference effect $(P<0.001)$ in Sod3 mRNA production at 48-h time point (Fig. 3A). Importantly, by transfecting siRNA for Sod3 (siSOD3) into TSH-stimulated $\mathrm{PC} \mathrm{Cl} 3$ cells, we formally proved that SOD3 has a role in regulating the mitogenic effect of TSH on thyroid cells, as the transfection of siSOD3 significantly $(P<0.05)$ reduced the in vitro BrdU incorporation from 33 to $15 \%$ (Fig. 3B). This mitogenic effect of SOD3 is in line with our earlier observations (Laurila et al. 2009).

Because previous studies have shown that the production of $\mathrm{H}_{2} \mathrm{O}_{2}$ in thyroid cells correlates with the stimulation of $\mathrm{T}_{3}$ and $\mathrm{T}_{4}$ production (Corvilain et al. 1994), we determined the dismutase activity of SOD3 in Cos-7 heterologous system to predict the participation of SOD3 in hormone synthesis. For this, we used control cells expressing DUOX2 (D2) and the activator of DUOX1 (DUOXA1 or A1), which together produce $\mathrm{O}_{2}^{--}$ rather than $\mathrm{H}_{2} \mathrm{O}_{2}$ (Zamproni et al. 2008, Morand et al. 2009). Transiently transfected SOD3 showed significant $(P<0.001)$ reduction in extracellular $\mathrm{O}_{2}^{--}$concentration indicating functionality of SOD3 in our cellular model (Fig. 3C). Finally, because DUOXes have been indicated as the main sources for $\mathrm{H}_{2} \mathrm{O}_{2}$ production in thyroid, we compared $\mathrm{H}_{2} \mathrm{O}_{2}$ levels produced by DUOX and SOD3 (Fig. 3D), and found that indeed, the SOD3derived $\mathrm{H}_{2} \mathrm{O}_{2}$ production was 28 -fold lower than by DUOX2-DUOXA2 pair $(P<0.05)$, suggesting a role for SOD3-mediated $\mathrm{H}_{2} \mathrm{O}_{2}$ production in controlling TSH-dependent thyroid growth and differentiation rather than in hormone production.

\section{SOD3 is down-regulated in thyroid cancer}

In line with the observation that SOD3 could be involved in the TSH-dependent proliferation/ dedifferentiation process, we decided to investigate the expression of Sod3 in malignant thyroid proliferative disorders, firstly by determining the mRNA 
A

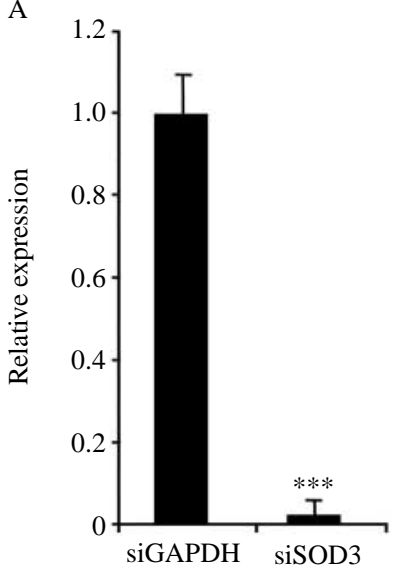

B

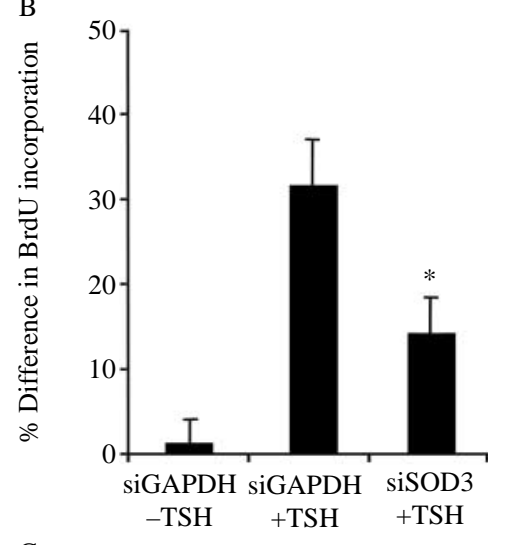

$\mathrm{C}$

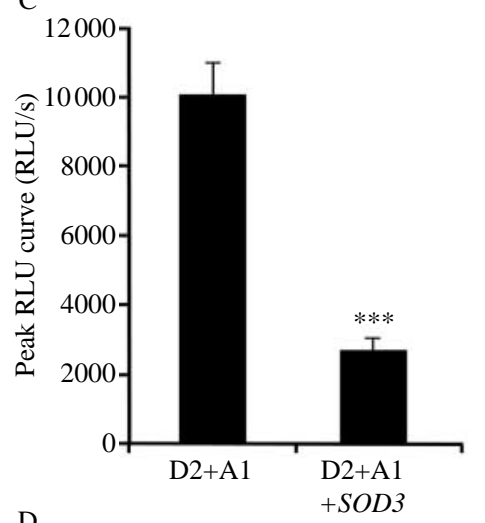

D

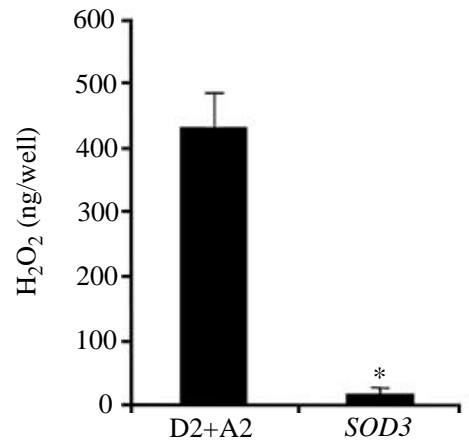

levels from three rat $\mathrm{PC} \mathrm{Cl} 3$ derived models of oncogene-dependent dedifferentiation, PC Braf, PC RET/PTC1, and PC E1A stable cell lines, which showed decreased Sod3 synthesis in correlation with oncogene-mediated transformation and dedifferentiation as compared with normal $\mathrm{PC} \mathrm{Cl3}$ cells (Fig. 4A). PC Braf cells showed twofold decreased $(P<0.05)$ mRNA synthesis, PC RET/PTC1 cells showed threefold decreased $(P<0.01)$ Sod 3 mRNA amount where as PC E1A cell model lacked almost completely the expression $(P<0.001)$ as compared with control $\mathrm{PC} \mathrm{Cl} 3$ cells.

To further study the effect of oncogene induced inhibition of SOD3 expression, we took advantage of an inducible oncogenic cellular model, doxycyclin RET/PTC1-inducible PC cells. As shown in Fig. 4B and $\mathrm{C}$, the increased expression of the RET/PTCl oncogene upon doxycyclin treatment correlated with a significant reduction in $\operatorname{Sod} 3$ expression at 24- and 72-h time points $(P<0.05$ at $24 \mathrm{~h}$ and $P<0.001$ at $72 \mathrm{~h})$, indicating that the different levels of Sod3 mRNA downregulation observed in Fig. 4A could also be due to the different expression levels of the specific oncogenes.

Since $\mathrm{H}_{2} \mathrm{O}_{2}$ represents the main product of $\mathrm{Sod} 3$ activation, we confirmed the decreased Sod 3 expression in PC RET/PTC1 and PC E1A cells by measuring the $\mathrm{H}_{2} \mathrm{O}_{2}$ levels, which were significantly $(P<0.001$ and $P<0.01$ respectively) decreased in transformed cells as compared with wild-type cells (Fig. 4D).

To finally move our observation to human models, we then compared DNA array data obtained from normal human thyroid, PTC, and ATC tissues, and showed significantly $(P<0.01)$ decreased SOD3 synthesis in papillary thyroid tumors and ATC tissue $(P<0.01)$ in line with in vitro cell models (Fig. 4A). These data were further confirmed by qRT-PCR analysis, which gave similar results (Fig. 4F).

Figure 3 Functional role of SOD3 in thyroid models. (A) RNAi knockdown of Sod3 in PC Cl3 cells. Quantitative RT-PCR showed significant $(P<0.001)$ Sod3 downregulation caused by siSOD3 interfering oligos. (B) BrdU incorporation analysis suggested significantly $(P<0.05)$ attenuated cell proliferation caused by siSOD3 in TSH-stimulated PC Cl3 cells. The

TSH-stimulated proliferation was decreased by $44 \%$ in siSOD3transfected cells as compared with siGAPDH-transfected cells. (C) The functionality of SOD3 to dismutase DUOX2/DUOXA1 (D2+A1) derived superoxide was tested in Cos-7 heterologous system. The data showed that SOD3 was able to dismutase the DUOX2/DUOXA1 produced superoxide significantly $(P<0.001)$ indicating functionality of the enzyme in this cell model. (D) SOD3-derived hydrogen peroxide production was tested in Cos-7 heterologous system. Properly folded DUOXA2 produced significantly $(P<0.05)$ higher concentration of $\mathrm{H}_{2} \mathrm{O}_{2}$ than SOD3. Transfection of SOD3 resulted in only minor increase in $\mathrm{H}_{2} \mathrm{O}_{2}$ synthesis suggesting that DUOX enzyme complex has the major role $\mathrm{H}_{2} \mathrm{O}_{2}$ synthesis in thyroid. 


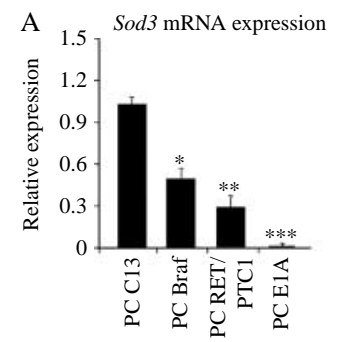

B PTCl mRNA expression

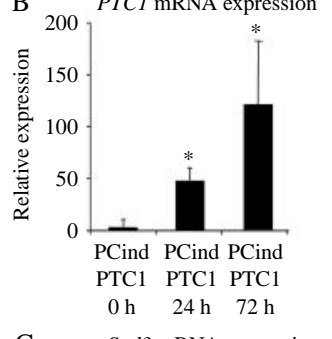

C Sod3 mRNA expression

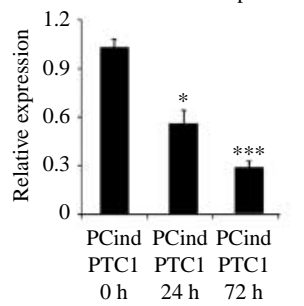

D $1.5 \mathrm{H}_{2} \mathrm{O}_{2}$ production
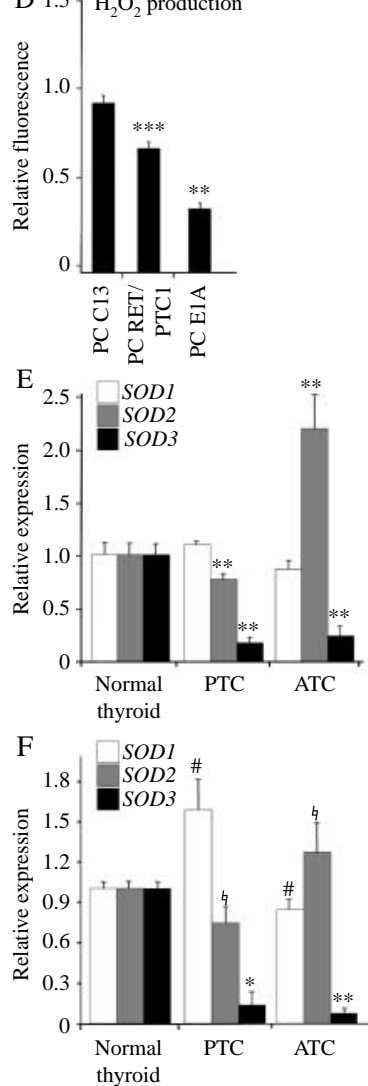

The expression of other isoenzymes, SOD1 and SOD2, were more variable in patient samples; SOD1 expression was mildly affected by tumorigenesis, whereas SOD2 was decreased in PTC patients $(P<0.01 / P<0.05$, DNA array/qRT-PCR $)$ and significantly increased in ATC thyroid tumors $(P<0.01 /$ $P<0.05$, DNA array/qRT-PCR). The in vitro and in vivo data therefore showed that SOD3 is expressed in normal thyroid tissue, induced by TSH together with thyroid differentiation markers (Dumont et al. 1992, Kondo et al. 2006), and reduced in in vitro transformation models and thyroid cancer samples.

\section{Discussion}

Thyroid tissue physiology requires continuous high concentration of $\mathrm{H}_{2} \mathrm{O}_{2}$ for thyroid hormone $\mathrm{T}_{3}$ and $\mathrm{T}_{4}$ synthesis which is, according to recent publications, produced mainly by DUOX (Dupuy et al. 1991, 2000, De Deken et al. 2002, Rigutto et al. 2007). Inactivating mutations of DUOX2 completely abolish $\mathrm{H}_{2} \mathrm{O}_{2}$ generation and thyroid hormone synthesis in human thyroids, and constitute a major cause of congenital hypothyroidism (Moreno et al. 2002). SODs are $\mathrm{H}_{2} \mathrm{O}_{2^{-}}$ producing isoenzymes that are responsible for balancing the reduction-oxidation reactions in different cellular compartments. In thyroid tissue, $\mathrm{H}_{2} \mathrm{O}_{2}$ is utilized in thyroid hormone production by transmembrane glycoprotein thyroperoxidase that both

Figure 4 SOD3 expression decreases upon thyroid cell transformation. (A) Quantitative RT-PCR analysis for Sod3 mRNA from wild-type rat $\mathrm{PC} \mathrm{Cl} 3$ cells and $\mathrm{PC} \mathrm{Cl} 3$ cells transformed with different oncogenes indicated decreased mRNA production correlating to the oncogene used for cell transformation. The Sod3 synthesis decreased $50 \%(P<0.05)$ in PC Braf cells, $60 \%(P<0.01)$ in PC RET/PTC1 cell model, and was almost completely abrogated $(P<0.001)$ in $\mathrm{PC} \mathrm{E} 1 \mathrm{~A}$ cells. (B and C) PC-inducible RET/PTC1 (PCindPTC1) cell model showed that the decreased Sod3 mRNA synthesis depends on the level of oncogene expression. The doxycyclininduced RET/PTC1 oncogene expression (B) correlates to the decreased Sod3 production (C). (D) Determination of $\mathrm{H}_{2} \mathrm{O}_{2}$ production. The fluorimetric measurement of $\mathrm{H}_{2} \mathrm{O}_{2}$ synthesis showed decreased $\mathrm{H}_{2} \mathrm{O}_{2}$ production in PC RET/PTC1 $(P<0.001)$ and PC E1A $(P<0.01)$ cells as compared with $\mathrm{PC} \mathrm{Cl} 3$ controls being in line with the reduced expression of the Sod3 enzyme. (E) Analysis of DNA array data from normal thyroid samples derived from papillary thyroid (PTC) and anaplastic thyroid (ATC) cancers showed reduced SOD3 expression in transformed tissues $(P<0.01)$. The differences of $S O D 1$ expression were statistically insignificant, whereas the expression of SOD2 was significantly $(P<0.05)$ decreased in PTC samples and significantly $(P<0.01)$ increased in ATC patients. (F) Real-time RT-PCR analysis supported the array data, showing that only SOD3 but not the other isoenzymes could be considered as a differentiation marker in cancer development. Both analyses, DNA array and qRT-PCR, showed that the expression of SOD1 and especially SOD2 was more variable. 
oxidizes and incorporates iodine to thyroglobulin, which is then further metabolized to thyroid hormones $\mathrm{T}_{3}$ and $\mathrm{T}_{4}$. In the present study, we therefore investigated the expression and role of SODs, more specifically extracellularly expressed SOD3, in thyroid cells in vitro models and further compared the results to patient samples data.

The expression analysis of different rat tissues suggested thyroid as a major expression site for the enzyme (Fig. 1). According to our previous studies, relatively low concentration of SOD3 in vitro or in vivo is able to induce a physiological response in the cells and in the surrounding extracellular tissue environment (Laukkanen et al. 2000, 2001b, 2002, Laurila et al. 2009), suggesting that even minor differences in the enzyme concentration can have an impact on cellular signaling and consequent biological effects.

We studied the SOD3 expression in benign thyroid enlargement models to determine the expression of the enzyme in the proliferative environment. Even though previous clinical analysis has demonstrated decreased total SOD activity in the plasma of Graves' disease patients (Wilson et al. 1989, Abalovich et al. 2003, Rybus-Kalinowska et al. 2008), a recent paper suggested increased Sod 3 mRNA production in thyroid caused by long-term iodine deprivation in murine models (Maier et al. 2007). Since both the synthesis of autoantibodies against TSH-R in Graves' disease and the diet iodine deprivation lead to increased TSH-R signaling and consequent thyroid activation, we investigated the Sod3 expression in experimental in vivo rat goiter model (Fig. 1). Increased Sod3 production in rat goiter model was in line with previous murine models (Maier et al. 2007), suggesting the participation of TSH in its expression in mouse and rat thyroid cells. However, analysis of patient samples did not show significant increase in SOD3 levels, which could be due to the existence of wide phenotypic variations in humans, ranging from mild to severe toxic hyperfunction of the gland. It is also noteworthy that unlike in rat normal thyroid and in rat $\mathrm{PC} \mathrm{Cl} 3$ thyroid cells, in normal human thyroid tissue, $S O D 1$ expression was fivefold higher than SOD3 mRNA production again indicating species-related differences (Fig. 1).

Because the TSH signaling is the main mediator of thyroid hyperfunction, we studied the effects of the different molecules of this pathway on Sod3 mRNA synthesis. TSH signals to TSH-R, a GPCR that activates $\mathrm{G} \alpha_{\mathrm{s}}$ and $\mathrm{G} \alpha_{\mathrm{q}}$ heterotrimeric G-proteins in human and rodents (Laugwitz et al. 1996). Activation of $\mathrm{G} \alpha_{\mathrm{s}}$ leads to the stimulation of cAMP, a positive modulator of thyroid cell proliferation and the expression of differentiation markers such as sodium iodide symporter and thyroperoxidase (Kogai et al. 1997, Pierce et al. 2002, van Staveren et al. 2006). The $\mathrm{G} \alpha_{\mathrm{q}}$ protein stimulation in thyroid activates DUOXderived $\mathrm{H}_{2} \mathrm{O}_{2}$ production, which is the limiting factor in thyroglobulin iodination and in thyroid hormone $\mathrm{T}_{3}$ and $\mathrm{T}_{4}$ synthesis (Corvilain et al. 1994). To determine the role of Sod3 in thyroid in vitro model, we utilized the $\mathrm{PC} \mathrm{Cl} 3$ cell line that according to our present data contains higher concentration of SOD3 than other isoenzymes and is therefore responding to SOD3mediated redox changes (Fig. 1H). By studying the effect of TSH signaling in these cells, we identified a novel GPCR-mediated induction of Sod3 through both, a cAMP and phosphatidylinositol-mediated way, suggesting a role for the enzyme in thyroid physiology (Fig. 2). Since GPCR-mediated signal transduction plays a significant role also in other tissues, the current data could potentially further explain previous observations of SOD3-mediated effects in injury models (Laukkanen et al. 2002, Brasen et al. 2007).

In order to investigate the functional effect of the enzyme in thyroid environment, we used siRNA and overexpression of SOD3 in heterologous Cos-7 model to study the proliferation and level of $\mathrm{H}_{2} \mathrm{O}_{2}$ production respectively (Fig. 3). According to the present data, knockdown of $\operatorname{Sod} 3$ is able to attenuate TSH-stimulated proliferation proving a role for the

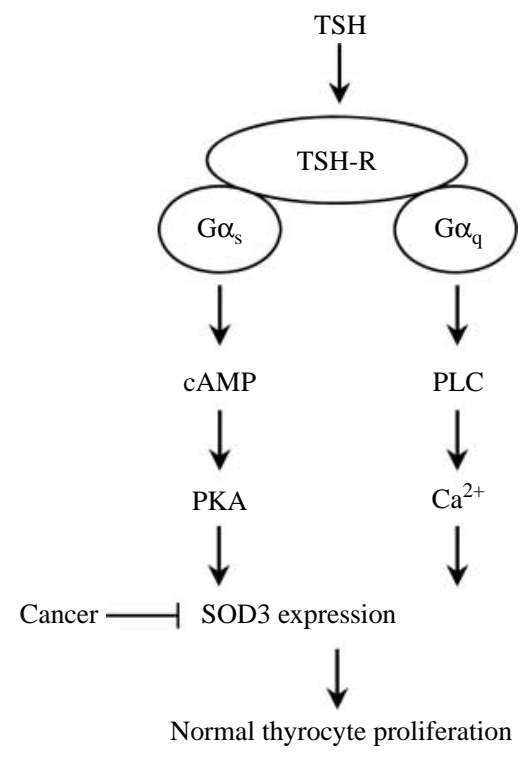

Figure 5 Scheme for activation of Sod3 transcription in thyroid cells. TSH stimulation leads to signal transduction via cAMP-PKA and PLC-Ca ${ }^{2+}$ routes that both increase Sod3 mRNA synthesis. In normal thyroid, the increased Sod3 production has a role in thyrocyte proliferation where as in thyroid cancer the signal transduction route leading to increased Sod3 levels is silenced, as a result of the loss of differentiation markers. 
enzyme in normal thyroid proliferation. In heterologous Cos-7 model, the transfected SOD3 reduced extracellular superoxide generation by mismatched DUOX1 and DUOXA2, but the SOD3 derived $\mathrm{H}_{2} \mathrm{O}_{2}$ was significantly lower than the $\mathrm{H}_{2} \mathrm{O}_{2}$ produced by matched DUOX2 and DUOXA2 at equal levels of expression, suggesting that, differently from DUOXes, SOD3 is not directly regulating thyroid hormone synthesis.

Finally, because the TSH signaling, as a differentiation marker, is down-regulated in cancer, we analyzed different $\mathrm{PC} \mathrm{Cl} 3$ derived cancer cellular models and showed reduced expression of the Sod3 mRNA, depending on both the specific oncogene used to transform the cells and the level of the oncogene expression (Fig. 4A-C).

To further analyze the SOD expression in thyroid tumorigenesis, we determined the mRNA expressions from human patient samples. Similarly to in vitro models, in both, papillary and anaplastic cancer tissue samples, we observed a reduced SOD3 expression, suggesting that this gene behaves as a thyroid differentiation marker reduced in malignant transformation (Fig. 4E and F).

In conclusions, we have shown a novel TSH stimulation-dependent GPCR-mediated signal transduction pathway activating Sod3 mRNA production in rat thyroid $\mathrm{PC} \mathrm{Cl} 3$ cell line. We have further demonstrated differentiation-dependent SOD3 expression both in vitro and in vivo in patient samples. The finding suggests that SOD3 is involved in TSH mitogen effect in normal thyrocytes, a pathway that is disrupted in thyroid cancer (Fig. 5).

\section{Declaration of interest}

The authors declare that there is no conflict of interest that could be perceived as prejudicing the impartiality of the research reported.

\section{Funding}

This work was supported by Academy of Finland, Sigrid Juselius Foundation, Paolo Foundation, AIRC, and European Community Contract FP6-36495 (GenRisk-T).

\section{Author contribution statement}

L E Laatikainen, M D Castellone, A Hebrant, C Hoste, M C Cantisani, J P Laurila, G Salvatore, P Salerno, F Basolo, $\mathrm{J}$ Näsman, and $\mathrm{M} O$ Laukkanen contributed to the experimental part of the work; M D Castellone, J Näsman, J E Dumont, M Santoro, and M O Laukkanen contributed to the design of the experiments and editing of the manuscript; J E Dumont, M Santoro, and M O Laukkanen provided funding for the research.

\section{Acknowledgements}

The authors would like to thank Prof Stefan L Marklund, Prof Alfredo Fusco, and Dr Silvio Gutkind for providing materials.

\section{References}

Abalovich M, Llesuy S, Gutierrez S \& Repetto M 2003 Peripheral parameters of oxidative stress in Graves' disease: the effects of methimazole and 131 iodine treatments. Clinical Endocrinology 59 321-327.

al-Alawi N, Rose DW, Buckmaster C, Ahn N, Rapp U, Meinkoth J \& Feramisco JR 1995 Thyrotropin-induced mitogenesis is Ras dependent but appears to bypass the Raf-dependent cytoplasmic kinase cascade. Molecular Cell Biology 15 1162-1168.

Aslan M \& Ozben T 2003 Oxidants in receptor tyrosine kinase signal transduction pathways. Antioxidants \& Redox Signaling 5 5781-5788.

Benard B \& Brault J 1971 Production of peroxide in the thyroid. Canadian Medical Association 100 701-705.

Brasen JH, Leppanen O, Inkala M, Heikura T, Levin M, Ahrens F, Rutanen J, Pietsch H, Bergqvist D, Levonen AL et al. 2007 Extracellular superoxide dismutase accelerates endothelial recovery and inhibits in-stent restenosis in stented atherosclerotic Watanabe heritable hyperlipidemic rabbit aorta. Journal of the American College of Cardiology 50 2249-2253.

Corvilain B, van Sande J, Laurent E \& Dumont JE 1991 The $\mathrm{H}_{2} \mathrm{O}_{2}$-generating system modulates protein iodination and the activity of the pentose phosphate pathway in dog thyroid. Endocrinology 128 779-785.

Corvilain B, Laurent E, Lecomte M, Vansande J \& Dumont JE 1994 Role of the cyclic adenosine $3^{\prime}, 5^{\prime}$-monophosphate and the phosphatidylinositol- $\mathrm{Ca}^{2+}$ cascades in mediating the effects of thyrotropin and iodide on hormone synthesis and secretion in human thyroid slices. Journal of Clinical Endocrinology and Metabolism 79 152-159.

De Deken X, Wang D, Dumont JE \& Miot F 2002 Characterization of ThOX proteins as components of the thyroid $\mathrm{H}(2) \mathrm{O}(2)$-generating system. Experimental Cell Research 273 187-196.

Dumont JE, Jauniaux JC \& Roger PP 1989 The cyclic AMPmediated stimulation of cell proliferation. Trends in Biochemical Sciences 14 67-71.

Dumont JE, Lamy F, Roger P \& Maenhaut C 1992 Physiological and pathological regulation of thyroid cell proliferation and differentiation by thyrotropin and other factors. Physiological Reviews 72 667-697.

Duprez L, Parma J, Van Sande J, Allgeier A, Leclere J, Schvartz C, Delisle MJ, Decoulx M, Orgiazzi J, Dumont J et al. 1994 Germline mutations in the thyrotropin receptor gene cause non-autoimmune autosomal dominant hyperthyroidism. Nature Genetics 7 396-401.

Dupuy C, Virion A, Ohayon R, Kaniewski J, Deme D \& Pommier J 1991 Mechanism of hydrogen peroxide 
formation catalyzed by NADPH oxidase in thyroid plasma membrane. Journal of Biological Chemistry 266 3739-3743.

Dupuy C, Pomerance M, Ohayon R, Noel-Hudson MS, Deme D, Chaaraoui M, Francon J \& Virion A 2000 Thyroid oxidase (THOX2) gene expression in the rat thyroid cell line FRTL-5. Biochemical and Biophysical Research Communications 277 287-292.

Fusco A, Berlingieri MT, Di Fiore PP, Portella G, Grieco M \& Vecchio G 1987 One- and two-step transformations of rat thyroid epithelial cells by retroviral oncogenes. Molecular Cell Biology 7 3365-3370.

Guyton KZ, Liu Y, Gorospe M, Xu Q \& Holbrook NJ 1996 Activation of mitogen-activated protein kinase by $\mathrm{H}_{2} \mathrm{O}_{2}$. Role in cell survival following oxidant injury. Journal of Biological Chemistry 271 4138-4142.

Hatori N, Sjoquist PO, Marklund SL \& Ryden L 1992 Effects of recombinant human extracellular-superoxide dismutase type $\mathrm{C}$ on myocardial infarct size in pigs. Free Radical Biology \& Medicine 13 221-230.

Hebrant A, Van Sande J, Roger PP, Patey M, Klein M, Bournaud C, Savagner F, Leclere J, Dumont JE, van Staveren WC et al. 2009 Thyroid gene expression in familial nonautoimmune hyperthyroidism shows common characteristics with hyperfunctioning autonomous adenomas. Journal of Clinical Endocrinology and Metabolism 94 2602-2609.

Karlsson K \& Marklund SL 1987 Heparin-induced release of extracellular superoxide dismutase to human blood plasma. Biochemical Journal 242 55-59.

Kogai T, Endo T, Saito T, Miyazaki A, Kawaguchi A \& Onaya T 1997 Regulation by thyroid-stimulating hormone of sodium/iodide symporter gene expression and protein levels in FRTL-5 cells. Endocrinology 138 2227-2232.

Kondo T, Ezzat S \& Asa SL 2006 Pathogenetic mechanisms in thyroid follicular-cell neoplasia. Nature Reviews. Cancer 6 292-306.

Konishi A, Aizawa T, Mohan A, Korshunov VA \& Berk BC 2004 Hydrogen peroxide activates the Gas6-Axl pathway in vascular smooth muscle cells. Journal of Biological Chemistry 279 28766-28770.

Kuroki M, Voest EE, Amano S, Beerepoot LV, Takashima S, Tolentino M, Kim RY, Rohan RM, Colby KA, Yeo KT et al. 1996 Reactive oxygen intermediates increase vascular endothelial growth factor expression in vitro and in vivo. Journal of Clinical Investigation 98 1667-1675.

Laezza C, Mazziotti G, Fiorentino L, Gazzerro P, Portella G, Gerbasio D, Carella C, Matarese G \& Bifulco M 2006 HMG-CoA reductase inhibitors inhibit rat propylthiouracil-induced goiter by modulating the ras-MAPK pathway. Journal of Molecular Medicine 84 967-973.

Laugwitz KL, Allgeier A, Offermanns S, Spicher K, Van Sande J, Dumont JE \& Schultz G 1996 The human thyrotropin receptor: a heptahelical receptor capable of stimulating members of all four $\mathrm{G}$ protein families. PNAS 93 116-120.
Laukkanen MO, Lehtolainen P, Turunen P, Aittomaki S, Oikari P, Marklund SL \& Yla-Herttuala S 2000 Rabbit extracellular superoxide dismutase: expression and effect on LDL oxidation. Gene 254 173-179.

Laukkanen MO, Leppanen P, Turunen P, Tuomisto T, Naarala J \& Yla-Herttuala S 2001 EC-SOD gene therapy reduces paracetamol-induced liver damage in mice. Journal of Gene Medicine 3 321-325.

Laukkanen MO, Kivela A, Rissanen T, Rutanen J, Karkkainen MK, Leppanen O, Brasen JH \& Yla-Herttuala S 2002 Adenovirus-mediated extracellular superoxide dismutase gene therapy reduces neointima formation in balloon-denuded rabbit aorta. Circulation 106 1999-2003.

Laurila JP, Castellone MD, Curcio A, Laatikainen LE, Haaparanta-Solin M, Gronroos TJ, Marjamaki P, Martikainen S, Santoro M \& Laukkanen MO 2009 Extracellular superoxide dismutase is a growth regulatory mediator of tissue injury recovery. Molecular Therapy 17 448-454.

Levey HA 1963 Relationship of age to pituitary TSH levels and PTU-induced goitrogenesis in the rat. American Journal of Physiology 205 837-841.

Ludgate ME \& Vassart G 1995 The thyrotropin receptor as a model to illustrate receptor and receptor antibody diseases. Bailliere's Clinical Endocrinology and Metabolism 9 95-113.

Maier J, van Steeg H, van Oostrom C, Paschke R, Weiss RE \& Krohn K 2007 Iodine deficiency activates antioxidant genes and causes DNA damage in the thyroid gland of rats and mice. Biochimica et Biophysica Acta 1773 990-999.

Marklund SL 1984 Extracellular superoxide dismutase and other superoxide dismutase isoenzymes in tissues from nine mammalian species. Biochemical Journal 222 649-655.

Mehdi MZ, Pandey NR, Pandey SK \& Srivastava AK 2005 $\mathrm{H}_{2} \mathrm{O}_{2}$-induced phosphorylation of ERK1/2 and PKB requires tyrosine kinase activity of insulin receptor and c-Src. Antioxidants \& Redox Signaling 7 1014-1020.

Morand S, Ueyama T, Tsujibe S, Saito N, Korzeniowska A \& Leto TL 2009 Duox maturation factors form cell surface complexes with Duox affecting the specificity of reactive oxygen species generation. FASEB Journal 23 1205-1218.

Moreno JC, Bikker H, Kempers MJ, van Trotsenburg AS, Baas F, de Vijlder JJ, Vulsma T \& Ris-Stalpers C 2002 Inactivating mutations in the gene for thyroid oxidase 2 (THOX2) and congenital hypothyroidism. New England Journal of Medicine 347 95-102.

Pierce KL, Premont RT \& Lefkowitz RJ 2002 Seventransmembrane receptors. Nature Reviews. Molecular Cell Biology 3 639-650.

Rao GN 1997 Protein tyrosine kinase activity is required for oxidant-induced extracellular signal-regulated protein kinase activation and c-fos and c-jun expression. Cell Signalling 9 181-187. 
Rao GN \& Berk BC 1992 Active oxygen species stimulate vascular smooth muscle cell growth and proto-oncogene expression. Circulation Research 70 593-599.

Rigutto S, Hoste C, Dumont JE, Corvilain B, Miot F \& De Deken X 2007 Duox1 is the main source of hydrogen peroxide in the rat thyroid cell line $\mathrm{PCCl} 3$. Experimental Cell Research 313 3892-3901.

Rybus-Kalinowska B, Zwirska-Korczala K, Kalinowski M, Kukla M, Birkner E \& Jochem J 2008 Activity of antioxidative enzymes and concentration of malondialdehyde as oxidative status markers in women with newly diagnosed Graves-Basedow disease and after thiamazole therapy leading to euthyroidism. Polish Archives of Internal Medicine 118 420-425.

Saito S, Frank GD, Mifune M, Ohba M, Utsunomiya H, Motley ED, Inagami T \& Eguchi S 2002 Ligandindependent trans-activation of the platelet-derived growth factor receptor by reactive oxygen species requires protein kinase C-delta and c-Src. Journal of Biological Chemistry 277 44695-44700.

Santoro M, Melillo RM, Grieco M, Berlingieri MT, Vecchio G \& Fusco A 1993 The TRK and RET tyrosine kinase oncogenes cooperate with ras in the neoplastic transformation of a rat thyroid epithelial cell line. Cell Growth and Differentiation 4 77-84.
Sjoquist PO \& Marklund SL 1992 Endothelium bound extracellular superoxide dismutase type $\mathrm{C}$ reduces damage in reperfused ischaemic rat hearts. Cardiovascular Research 26 347-350.

Song Y, Driessens N, Costa M, De Deken X, Detours V, Corvilain B, Maenhaut C, Miot F, Van Sande J, Many MC et al. 2007 Roles of hydrogen peroxide in thyroid physiology and disease. Journal of Clinical Endocrinology and Metabolism 92 3764-3773.

van Staveren WC, Solis DW, Delys L, Venet D, Cappello M, Andry G, Dumont JE, Libert F, Detours V \& Maenhaut C 2006 Gene expression in human thyrocytes and autonomous adenomas reveals suppression of negative feedbacks in tumorigenesis. PNAS 103 413-418.

Wang X, McCullough KD, Franke TF \& Holbrook NJ 2000 Epidermal growth factor receptor-dependent Akt activation by oxidative stress enhances cell survival. Journal of Biological Chemistry 275 14624-14631.

Wilson R, Chopra M, Bradley H, McKillop JH, Smith WE \& Thomson JA 1989 Free radicals and Graves' disease: the effects of therapy. Clinical Endocrinology 30 429-433.

Zamproni I, Grasberger H, Cortinovis F, Vigone MC, Chiumello G, Mora S, Onigata K, Fugazzola L, Refetoff S, Persani L et al. 2008 Biallelic inactivation of the dual oxidase maturation factor 2 (DUOXA2) gene as a novel cause of congenital hypothyroidism. Journal of Clinical Endocrinology and Metabolism 93 605-610. 